\title{
Humusica 1, Article 6: Terrestrial humus systems and forms - Hydro intergrades
}

Augusto Zanella ${ }^{a} *$, Jean-François Ponge ${ }^{b}$, Jérôme Juilleret ${ }^{c}$, Rein de Waal ${ }^{d}$, Renée-Claire Le Bayon ${ }^{e}$, Andrea Vacca ${ }^{f}$, Anna Andreetta ${ }^{\mathrm{g}}$

${ }^{a}$ University of Padua, Padua, Italy

${ }^{\mathrm{b}}$ Muséum National d'Histoire Naturelle, Paris, France

${ }^{\mathrm{c}}$ Luxembourg Institute of Science and Technology, Belvaux, Luxembourg

${ }^{\mathrm{d}}$ University of Wageningen, Wagenningen, The Netherlands

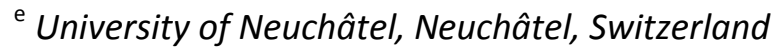

${ }^{\mathrm{f}}$ University of Cagliari, Cagliari, Italy

${ }^{\mathrm{g}}$ University of Firenze, Firenze, Italy

Keywords: Humus; Hydro intergrades; Soil hydromorphic properties; Hydromorphic soil; Humusica

\section{ABSTRACT}

In this article, we present the Terrestrial intergrades from never or only few days submersed humipedons, without permanent hydromorphic signs, until humipedons with presence of signs of partial asphyxia. Specific terms are defined and diagnostic horizons illustrated, both with the help of text explanations and photographs. The article ends with a table working as a classification field key.

\footnotetext{
${ }^{*}$ Corresponding author. Author of the photographs: A. Zanella

E-mail addresses: augusto.zanella@unipd.it (A. Zanella), ponge@mnhn.fr (J.-F. Ponge), jerome.juilleret@list.lu (J. Juilleret), rein.dewaal@wur.nl (R. de Waal), claire.lebayon@unine.ch (R.-C. Le Bayon), avacca@unica.it (A. Vacca), anna.andreetta@unifi.it (A. Andreetta).
} 


\section{Introduction}

Soil pores may be filled with water, air and living organisms. Air carries into the soil oxygen and nitrogen, both very important elements for soil organisms (roots, bacteria, fungi and animals) (Gobat et al., 2004). When water replaces the air in the soil, soil organisms must face a period of anoxia and sometimes asphyxia (Hattori et al., 1976). Aerobic bacteria are most active in unsaturated moist soils, but anoxic hostile conditions will not completely kill bacteria, they will stop growing and get into a dormant stage (Bouthier et al., 2014). As for macro-organisms, earthworms without oxygen will suffocate and try to escape from their galleries. However, worm experts say that earthworms could survive for several weeks in water, providing there is sufficient oxygen in the water to support them. Earthworms do not surface to avoid drowning. We see them out of soil after rain because they can move around without dehydrating (Lee, 1985; Boyle et al., 1997; Edwards and Bater, 1992; Edwards, 2004) but also because the vibrations caused by raindrops mimic those emitted by predators such as moles (Catania, 2008). For some species, growth and reproduction are maximal at a soil moisture of $80 \%$ (Hallatt et al., 1992). Anecic earthworms influence the soil porosity and have an impact on the soil water and mineral elements availability for plants (Andriuzzi et al., 2015; Bouché and Al-Addan, 1997; Le Bayon and Binet, 2006).

Concomitantly with soil organisms, specific plant communities grow on hydromorphic soils. Considering only Terrestrial ecosystems (not peat or always submerged soils, related to Histo humus forms and soils), plant phytosociologists list along a gradient from wet to fresh soils, forests belonging to Alnion glutinosae (dominant trees: Alnus glutinosa), Alno-Padion (Alnus glutinosa, Fraxinus excelsior, Prunus padus) and Carpinion (Carpinus betulus) phytosociological alliances (For the lists of plants refer to: Zanella, 1990; Géhu and Géhu, 1977; Noirfalaise, 1984; Oberdorfer, 1957). Rivers are also bordered by hydromorphic soils, which support linear plant formations assigned to Alnion incanae (rather mountain, rocky rivers) and Salicion albae (plain) phytosociological alliances. More complete data and geographical distribution in Europe of hydromorphic soil habitats are available on the website of the European Environment Agency (EEA, 2017). In the EUNIS habitat classification, the forests with hydromorphic soils are listed in Annexe 1 at levels G1.1 (Riparian and gallery woodland, with dominant [Alnus], [Betula], [Populus] or [Salix]), G1.2 (Mixed riparian floodplain and gallery woodland), G1.3 (Mediterranean riparian woodland) and G1.4 (Broadleaved swamp woodland not on acid peat). Broadleaved swamp woodland on acid peat (Histic humus forms or Histo soils) are placed in a separate G1.5 section. Besides a gradient from semiterrestrial forests to humid forests, there is also a gradient from quacking mires, reeds, sedges to half natural wet to humid grasslands and Sphagnum-dominated bog-like short vegetation. A LIFE publication entitled "LIFE and Europe's wetlands: Restoring a vital ecosystem" is also available (Silva et al., 2007) and furnishes very useful information about geographical distribution in Europe of these sites, as well as fauna (especially birds and amphibians), flora and human exploitation, with the aim to support their conservation.

\section{Specific terms and diagnostic horizons}


Specific terms and diagnostic horizons are equivalent to the ones presented in preceding publications (Zanella et al., 2011a, b). In the current version, the "g" letter indicating the presence of hydromorphic features is set before the capital letter of each concerned horizon, avoiding confusion with the same letter used in other soil description guides (in the French Référentiel Pédologique, " $\mathrm{g}$ " is used as horizon letter for defining a group the Redoxisoils main reference) with different significance. Specific terms and diagnostic horizons are reported in a synthetic manner, as in a key of classification (as in Humusica 1, article 4, for Terrestrial humus systems and forms). In all humipedon investigations, a minimum horizon thickness for description, diagnosis and sampling purposes has been established at $3 \mathrm{~mm}$. Below this threshold, the horizon is considered discontinuous if clearly in patches or absent if indiscernible from other neighbouring horizons. Only organic horizons OL, OF, $\mathrm{OH}, \mathrm{H}$ (for Histic profiles) and upper organic-mineral A horizons are considered in Humipedon classification of Humusica articles. To identify mineral horizons, we followed the Guidelines of Soil Description FAO (2006) and preconize the use of WRB (IUSS Working Group WRB, 2015) to complement entire soil classifications. All lowercase letters used for humipedon horizons description precede the horizon capital letter as prefix, avoiding confusion with suffix soil lowercase letters use in "classical" soil description recommendation.

\subsection{Hydromorphic properties}

In the description of humipedon horizon, the letter " $\mathrm{g}$ " is used before the horizon letter as a prefix (a lower case letter for hydromorphic properties and a capital letter for horizon; example: gA). The prefix " $\mathrm{g}$ " is used for Terrestrial organic $(\mathrm{O}$ and $\mathrm{H})$ as well as organic-mineral $(A)$ horizons to highlight water influence on those horizons. However, recognizing criteria are different in these two categories of horizons. In $\mathrm{O}$ and $\mathrm{H}$ horizons, prefix " $\mathrm{g}$ " is used when the organic horizons are very dark, sign of a long period of water saturation; in organic-mineral A horizon, prefix " $\mathrm{g}$ " designates those horizons in which a distinct pattern of mottling occurs and reflects alternating conditions of oxidation and reduction of iron oxides, caused by seasonal surface waterlogging. The mottling means that either reductimorphic and/or oxymorphic colours are present at the level of the cited horizon (gA). Reductimorphic colours reflects permanently wet (gley) conditions (colours indicating the presence of reduced iron, bluish-green grey or bright blue-green according to the presence/absence of organic matter and concentration of iron), while oximorphic reflects oxidizing conditions, as in the capillary fringe and in the surface horizons of soils with fluctuating groundwater levels (pseudogley). Availability of macronutrients like phosphate and nitrogen is also influenced by the aeration-water saturation of the root zone (redox-processes) (Abuarab et al., 2013; Dickson and Broyer, 1972). Oximorphic colours indicate the presence of precipitated oxidised iron: reddish brown, bright yellowish brown, orange, dark orange and pale yellow, according to the proportion of hematite (red) and goethite (yellow) and other ferric minerals (Torrent et al., 1983). Reductimorphic and oximorphic colours cover only some parts of the soil volume when the hydromorphic properties are weakly expressed. Bluish-green colours are usually unstable and often oxidize to a reddish brown within a few hours of exposure to air. Oximorphic colours inside superficially grey soil aggregates mean a recent and unstable submersion of the aggregate. A horizon showing hydromorphic properties may 
be all grey in case of permanent submersion or more or less finely mottled grey and orange if phases of submersion/emersion (Fig. 1).

\subsection{Terrestrial hydromorphic organic horizons}

ORGANIC HORIZONS (gOL, gOF, gOH): organic horizons submerged and/or water-saturated for a non-protracted period of the year (less than 6 months per year) and showing the effects of temporary anoxia; carbon content reaches $20 \%$ or more (approximately $40 \%$ of total organic matter) by weight, in dried samples sieved at $1 \mathrm{~mm}$ thus removing living roots (Method: element analyser, ISO 10694, 1995). Horizons are still under saturated circumstances or drained.

gOL, gOF, gOH (from hydromorphic Terrestrial horizons, Figs. 2-4). Hydric organic horizons formed under non-prolonged water saturation (less than 6 months), periodically water-saturated and showing the effects of temporary anoxia. A prefix letter " $\mathrm{g}$ ", preceding the code of Terrestrial horizons, indicates the presence of hydromorphic features: plant remains becoming dark, glued together and often coloured (more evident than usual) along the venation of the leaves by black particles of humic component deposited here by water during the period of immersion; humic component often dark grey or black, massive and plastic, may be structured in faunal faecal pellets during aerated periods. Carbon content is $\geq 20 \%$ by weight. Humic component is less than $10 \%$ in volume (roots excluded) in gOL, between 10 and $70 \%$ in gOF and more than $70 \%$ in $\mathrm{gOH}$.

\subsection{Terrestrial hydromorphic organic-mineral horizons}

ORGANIC-MINERAL HORIZON (gA): submersed and/or water-saturated for a non-protracted period of the year (less than 6 months per year); carbon content is generally less than $7 \%$ by weight, in dry samples without living roots (Method: element analyser, ISO 10694, 1995).

gA (from Terrestrial A horizon and "g" hydromorphic properties, Figure 5). Hydric organicmineral horizons show evidence of temporary anoxia such as oxidation/reduction Fe-mottling colours (orange-red spots within grey to bluish-grey matrix) covering at least $1 / 3$ of the surface of the horizon profile; the carbon content is generally less than $7 \%$ by weight. All Terrestrial A horizons can show hydromorphic properties (examples: gzoA =hydromorphic zoogenic $A$ horizon, gnozA = hydromorphic non zoogenic $A$, gma $A$ = hydromorphic biomacrostructured $A$, gme $A$ = hydromorphic biomesostructured $A$, gmi $A$ = hydromorphic biomicrostructured $A$, gms $A=$ hydromorphic massive $A$, gsg $A=$ hydromorphic single grained $A$, gams $A=$ hydromorphic anthropogenic massive $A$, gama $A=$ hydromorphic biomacrostructured $A$, gszo $A$ = hydromorphic slightly zoogenic $A$, etc.). Sometimes these properties are only traces of past events and are not in accordance with the current hydrological situation. If carbon content is higher than $7 \%$ by weight, similarities with $\mathrm{mrA}$ or $\mathrm{HS}$ are possible. However, the structure of gmaA or gmeA horizons, mostly due to anecic and endogeic earthworms (faeces= macro- or mesoaggregates), and although partially destroyed by water, never 
becomes completely plastic and massive as in the mrA horizon. The carbon content of gzoA, gnozA, gmaA, gmeA, gmiA, gmsA, gsgA, gamaA, gameA, gszoA never reaches $20 \%$, which is the case in every kind of HS horizon.

\section{Names of Hydro intergrades}

When $\mathrm{gOH}$ or gA hydromorphic horizons are present, the prefix "Hydro" (from Hydros, water) is set before the name of the corresponding Terrestrial forms, without hyphenation. The presence of gOL or gOF in Terrestrial humus forms is possible but not sufficient for using the prefix Hydro. The reason is that wet black gOL and gOF horizons can be present in a humipedon that does not show hydromorphic properties in its other horizons. In this case, it is preferable to assign the humipedon to a "normal", not hydromorphic Terrestrial form.

Example of names (case of hydromorphic Mull):

Hydro Mull: OL, OF, gmaA (Figs. 5 and 6) or gOL, gOF, gA or OL, gA, or...

Examples of names (cases of hydromorphic Mor):

Hydro Mor= Hydro Eumor: OL or gOL/gOF and/or gnozOF/gnozOH and/or gzoOH and/or gnozA or gAE or A absent (Fig. 7).

Hydro Hemimor; OL or gOL/nozOF discontinuous or in pockets or gzoOF or zoOF/OH or $\mathrm{gOH} / \mathrm{gnozA}$ or gAE or A absent.

Hydro Humimor: OL or gOL/nozOF continuous/zoOH or gOH possible/nozOH or gnozOH/gnozA or gAE or A absent.

Hydro Eumor: OL or gOL/nozOF continuous/nozOH or gnozOH possible/gnozA or gAE or A absent (Fig. 7).

\section{Simplified table of classification of Terrestrial humus systems, forms and Hydro intergrades}

All Terrestrial humus systems and forms have been set in a single table (Fig. 8).

\section{References}

Abuarab, M., Mostafa, E., Ibrahim, M., 2013. Effect of air injection under subsurface drip irrigation on yield and water use efficiency of corn in a sandy clay loam soil. J. Adv. Res. 4, 493-499. 
Andriuzzi, W.S., Pulleman, M.M., Schmidt, O., Faber, J.H., Brussaard, L., 2015. Anecic earthworms (Lumbricus terrestris) alleviate negative effects of extreme rainfall events on soil and plants in field mesocosms. Plant Soil 397, 103-113.

Bouché, M.B., Al-Addan, F., 1997. Earthworms, water infiltration and soil stability: some new assessments. Soil Biol. Biochem. 29, 441-452.

Bouthier, A., Pelosi, C., Villenave, C., Pérès, G., Hedde, M., Ranjard, L., Vian, J.F., Peigne, J., Cortet, J., Bispo, A., Piron, D., 2014. Impact du travail du sol sur son fonctionnement biologique. In: Labreuche, J., Laurent, F., Roger-Estrade, J. (Eds.), Faut-il travailler le sol? Acquis et innovations pour une agriculture durable. Quae, Versailles, pp. 85-108. https://www.researchgate.net/profile/Mickael Hedde/publication/270895717 (Accessed 30 August 2017).

Boyle, K.E., Curry, J.P., Farrell, E.P., 1997. Influence of earthworms on soil properties and grass production in reclaimed cutover peat. Biol. Fertil. Soils 25, 20-26.

Catania, K.C., 2008. Worm grunting, fiddling, and charming: humans unknowingly mimic a predator to harvest bait. PLOS ONE 3, e3472.

Dickson, R.E., Broyer, T.C., 1972. Effects of aeration, water supply, and nitrogen source on growth and development of tupelo gum and bald cypress. Ecology 53, 626-634.

EEA, 2017. European Environment Agency. EUNIS Habitat Classification. https://www.eea.europa.eu/themes/biodiversity/eunis/eunis-habitat-classification (Accessed 30 August 2017).

Edwards, C.A., Bater, J.E., 1992. The use of earthworms in environmental management. Soil Biol. Biochem. 24, 1683-1689.

Edwards, C.A., 2004. Earthworm Ecology, $2^{\text {nd }}$ ed. CRC Press, Boca Raton.

FAO, 2006. Guidelines for Soil Description, $4^{\text {th }}$ ed. FAO, Rome.

Géhu, J.M., Géhu, J., 1977. Les forêts à géophytes des plaines et collines du Nord-Ouest de la France. Nat. Can. 104, 47-56.

Gobat, J.M., Aragno, M., Matthey, W., 2004. The Living Soil: Fundamentals of Soil Science and Soil Biology. Science Publishers, Enfield, NH.

Hallatt, L., Viljoen, S.A., Reinecke, A.J., 1992. Moisture requirements in the life cycle of Perionyx excavatus (Oligochaeta). Soil Biol. Biochem. 24, 1333-1340.

Hattori, T., Hattori, R., McLaren, A.D., 1976. The physical environment in soil microbiology: an attempt to extend principles of microbiology to soil microorganisms. CRC Crit. Rev. Microbiol. 4, 423-461.

IUSS Working Group WRB, 2015. World Reference Base for Soil Resources 2014, Update 2015: International Soil Classification System for Naming Soils and Creating Legends for Soil Maps. World Soil Resources Reports No. 106. FAO, Rome. 
Le Bayon, R.C., Binet, F., 2006. Earthworms change the distribution and availability of phosphorous in organic substrates. Soil Biol. Biochem. 38, 235-246.

Lee, K.E., 1985. Earthworms: Their Ecology and Relationships with Soils and Land Use. Academic Press, London.

Noirfalaise, A., 1984. Forêts et stations forestières en Belgique. Presses Agronomiques de Gembloux, Gembloux.

Oberdorfer, E., 1957. Süddeutsche Pflanzengesellschaften. Gustav Fischer, Jena.

Silva, J.P., Phillips, L., Jones, W., Eldridge, J., O'Hara, E., 2007. LIFE and Europe's Wetlands: Restoring a Vital Ecosystem. Office for Official Publications of the European Communities, Luxemburg. http://ec.europa.eu/environment/life/publications/lifepublications/lifefocus/documents/wetl ands.pdf (Accessed 30 August 2017).

Torrent, J., Schwertmann, U., Fechter, H., Alferez, F., 1983. Quantitative relationships between soil color and hematite content. Soil Sci. 136, 354-358.

Zanella, A., Jabiol, B., Ponge, J.F., Sartori, G., De Waal, R., Van Delft, B., Graefe, U., Cools, N., Katzensteiner, K., Hager, H., Englisch, M., Brêthes, A., Broll, G., Gobat, J.M., Brun, J.J., Milbert, G., Kolb, E., Wolf, U., Frizzera, L., Galvan, P., Kõlli, R., Baritz, R., Kemmers, R., Vacca, A., Serra, G., Banas, D., Garlato, A., Chersich, S., Klimo, E., Langohr, R., 2011a. European Humus Forms Reference Base. https://hal.archives-ouvertes.fr/hal-00541496 (Accessed 30 August 2017).

Zanella, A., Jabiol, B., Ponge, J.F., Sartori, G., De Waal, R., Van Delft, B., Graefe, U., Cools, N., Katzensteiner, K., Hager, H., Englisch, M., 2011b. A European morphofunctional classification of humus forms. Geoderma 164, 138-145.

Zanella, A., 1990. Apport à la connaissance phytosociologique et dynamique de la forêt de Nieppe. Doc. Phytosociol. 12, 245-256. 


\section{Figure captions}

Fig. 1. Hydromorphic properties. a-c: orange: oximorphic; Bluish-green: reductimorphic; d: artistically sensible students always play with the clay consistence of this material: small curved pig ears and dolphin thin crooked fins cannot be done with less than $35-40 \%$ of clay content. Even if this test is not very accurate, to combine science and art during teaching activities is always pleasant.

Fig. 2. Organic hydromorphic gOH horizon. This horizon resembles a very organic anA horizon, or a "more mineral than usual" and humid $\mathrm{OH}$ horizon.

Fig. 3. Organic hydromorphic gOF horizon. This horizon looks like a black fragmented litter within a watered brown mineral matrix.

Fig. 4. Organic hydromorphic gOL horizon. In water (anoxic conditions), litter becomes black or dark brown.

Fig. 5. Organic-mineral hydromorphic gmaA horizon. a) the whole profile. Due to periodical asphyxia, the litter biodegradation cannot run as fast as in a non-hydromorphic humus Mull system. Grey traces of earthworm galleries are visible in the orange/grey mass of the horizon; $b$ ) magnifying a piece of a biomacrostructured $A$ horizon, it is possible to individuate the typical large organic-mineral soil aggregates of a Mull system.

Fig. 6. Hydro Mull. OL and gmaA horizons, in humid grassland in Parisian region.

Fig. 7. Hydro Mor. OL, gOF, gOH horizons lying on a grey gley mineral horizon.

Fig. 8. Simplified table of classification of Terrestrial humus systems, forms and Hydro intergrades. Hydro = prefix to utilize if presence of hydromorphic (horizons periodically water-saturated, for a period of less than a few months per year), examples: $\mathrm{OL}+$ maA =Mesomull; $\mathrm{OL}+\mathrm{Ag}$ or $\mathrm{OLg}+\mathrm{Ag}=$ Hydro Mesomull; typical =tacit, without hydromorphic horizons = in typical terrestrial condition (horizons water-saturated less than a few days per year); possible = horizon present or absent or thickness $<2 \mathrm{~mm}$; the presence of hydromorphic organic $\mathrm{gOL}$ and gOF horizons is not sufficient for using the Hydro prefix for a humipedon when all other horizons are not hydromorphic; possible and mandatory = horizon present or absent or thickness $<2 \mathrm{~mm}$, but mandatory for using the Sagnic prefix; $\mathrm{OH}>2 \mathrm{~A}=$ thickness of $\mathrm{OH}$ horizon $>2$ times thickness of $A$ horizon; $A \geq O H / 2=$ thickness of $A$ horizon $\geq$ half the thickness of $\mathrm{OH}$ horizon; disc pock= horizon discontinuous or in pockets; $\geq 3 \mathrm{~cm}=$ thickness of indicated horizon $\geq 3 \mathrm{~cm}$; or = the indicated horizon could be present instead of another indicated horizon; and/or = the indicated horizon could be present with or instead of another indicated horizon. 


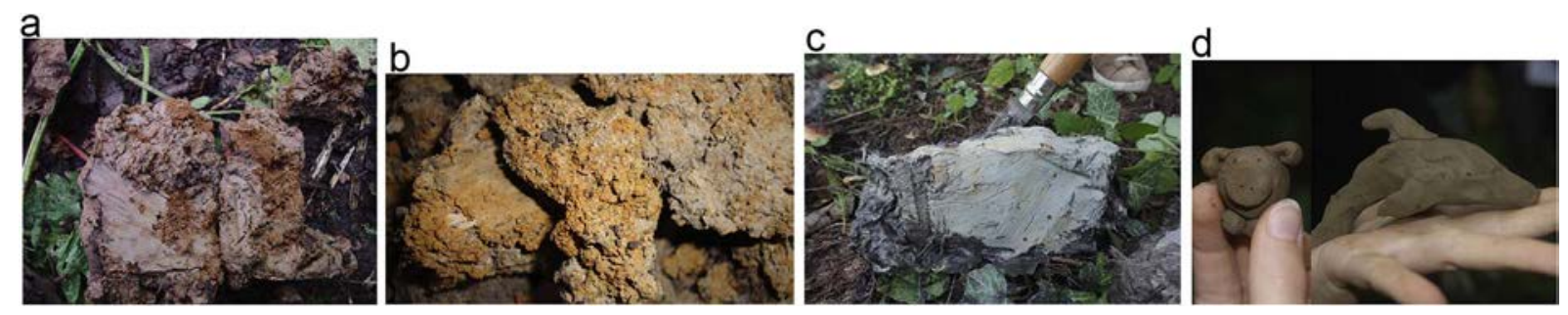

Fig. 1 


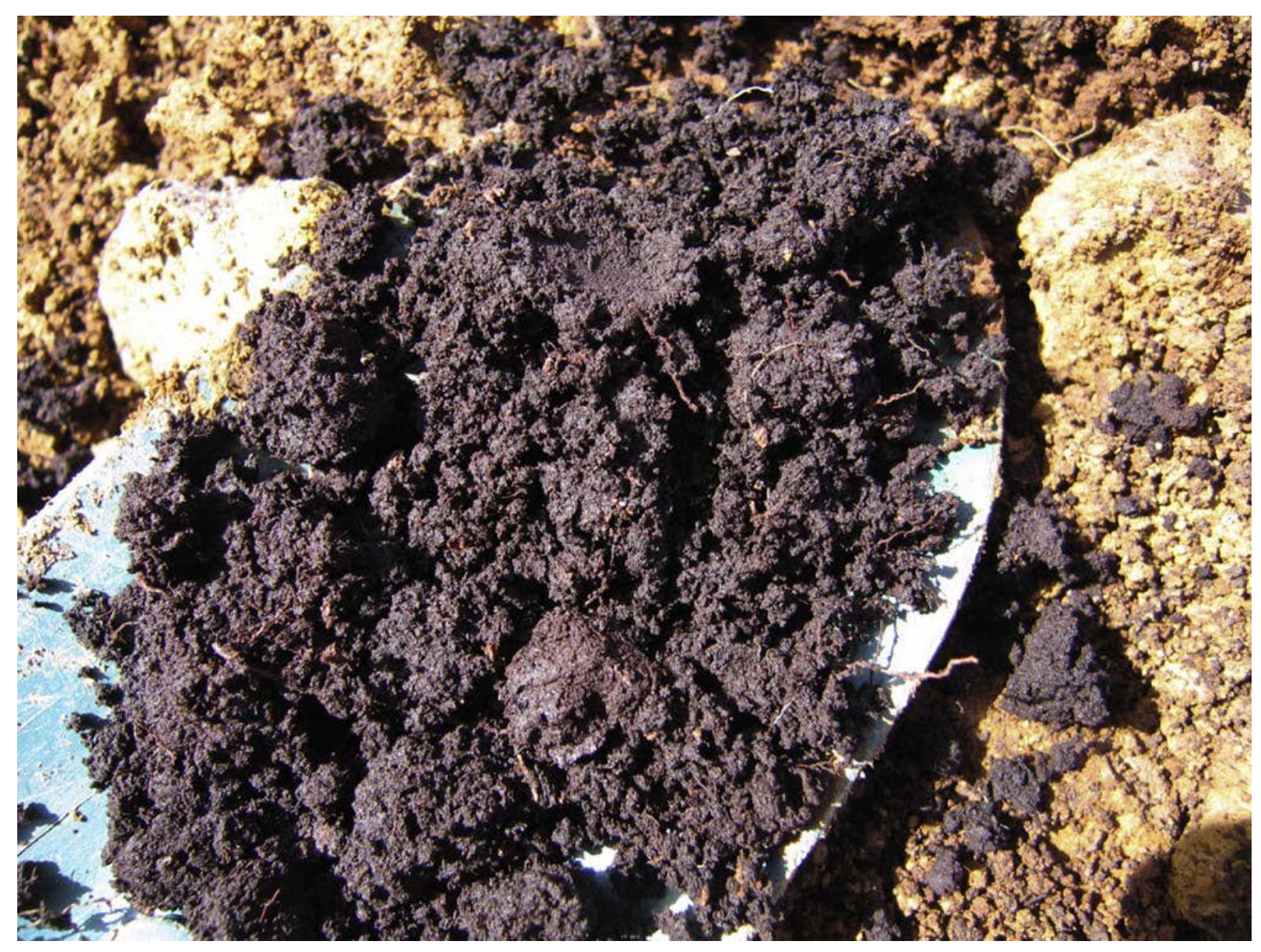

Fig. 2 


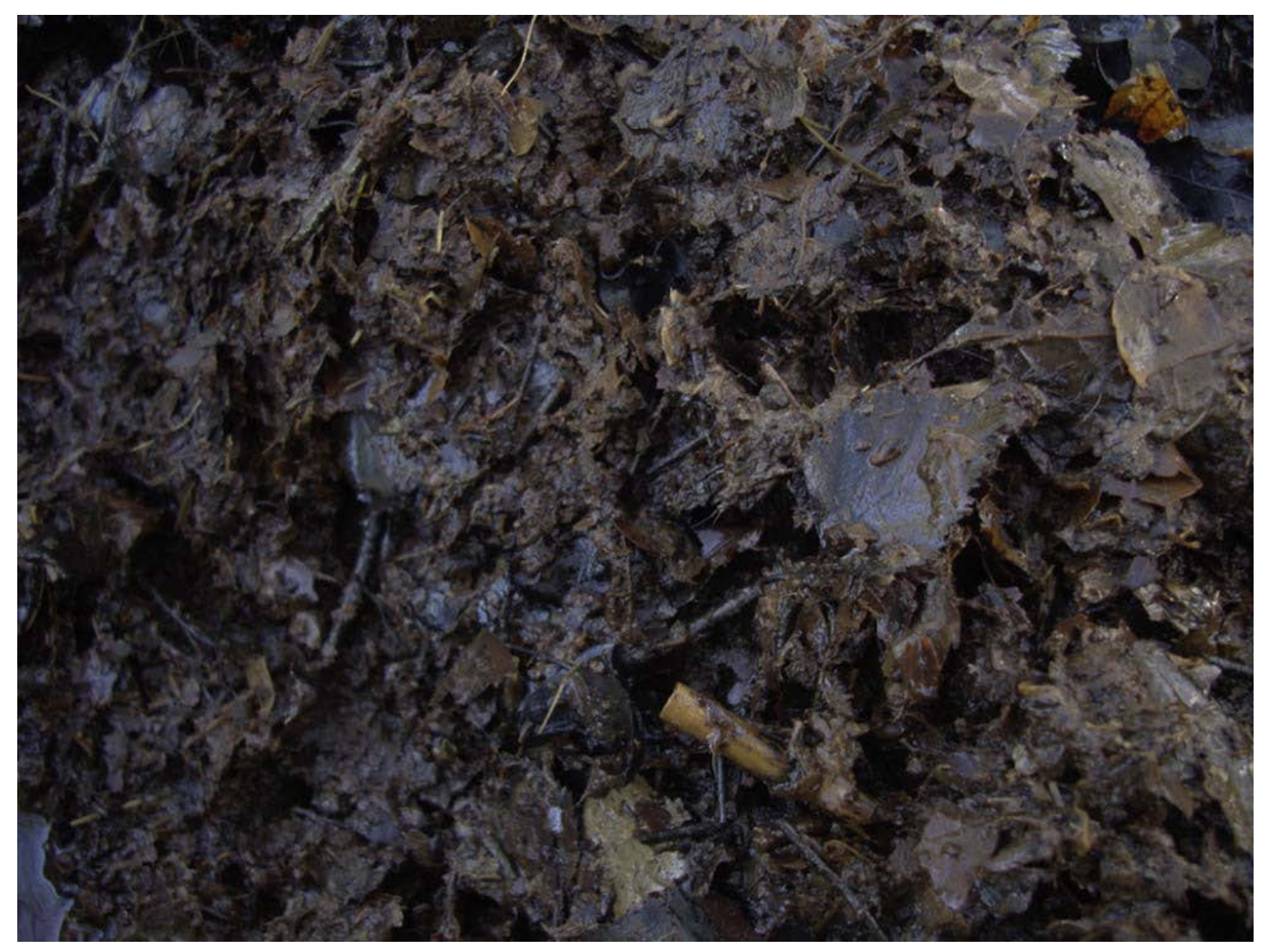

Fig. 3 


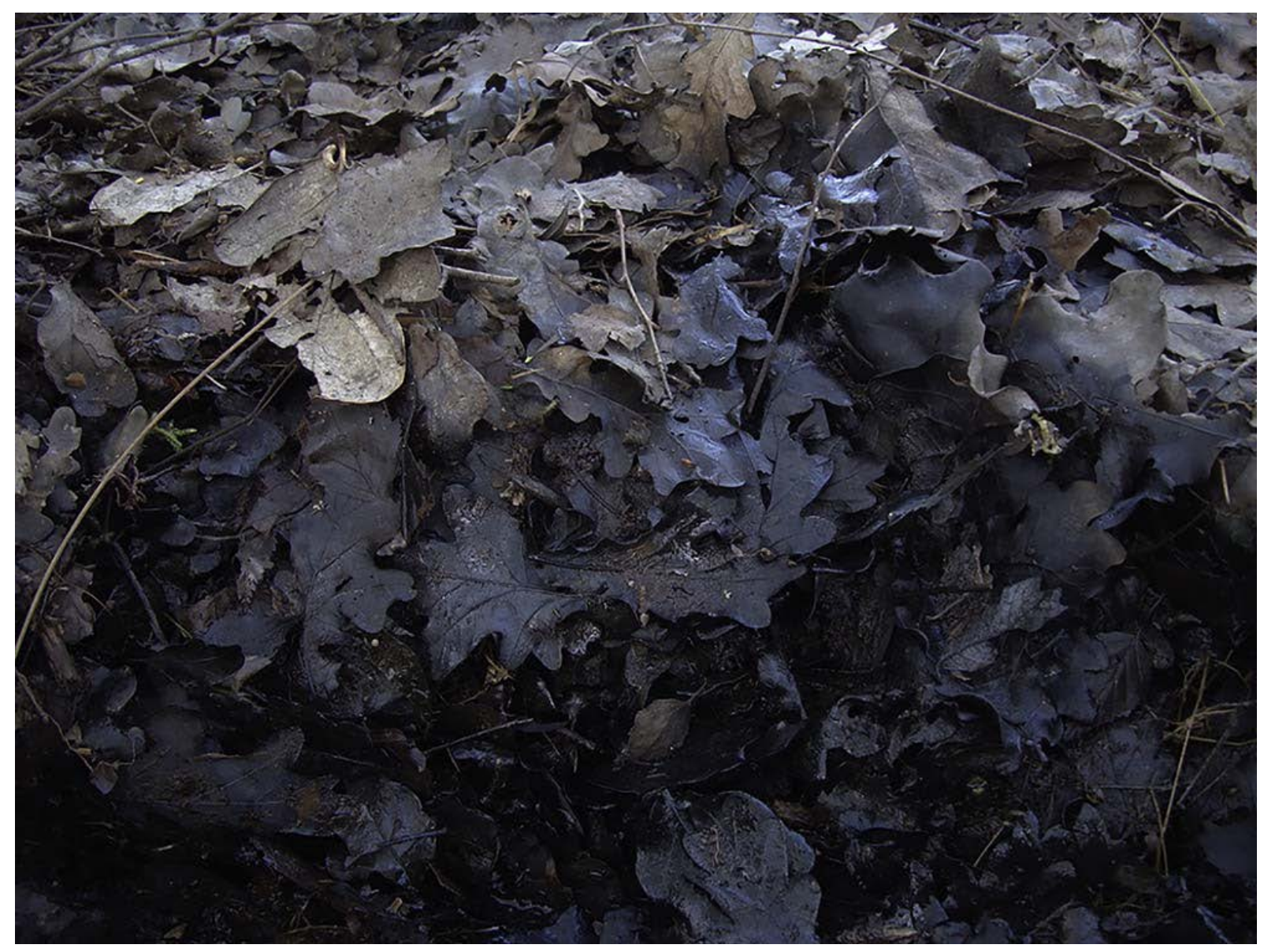

Fig. 4 

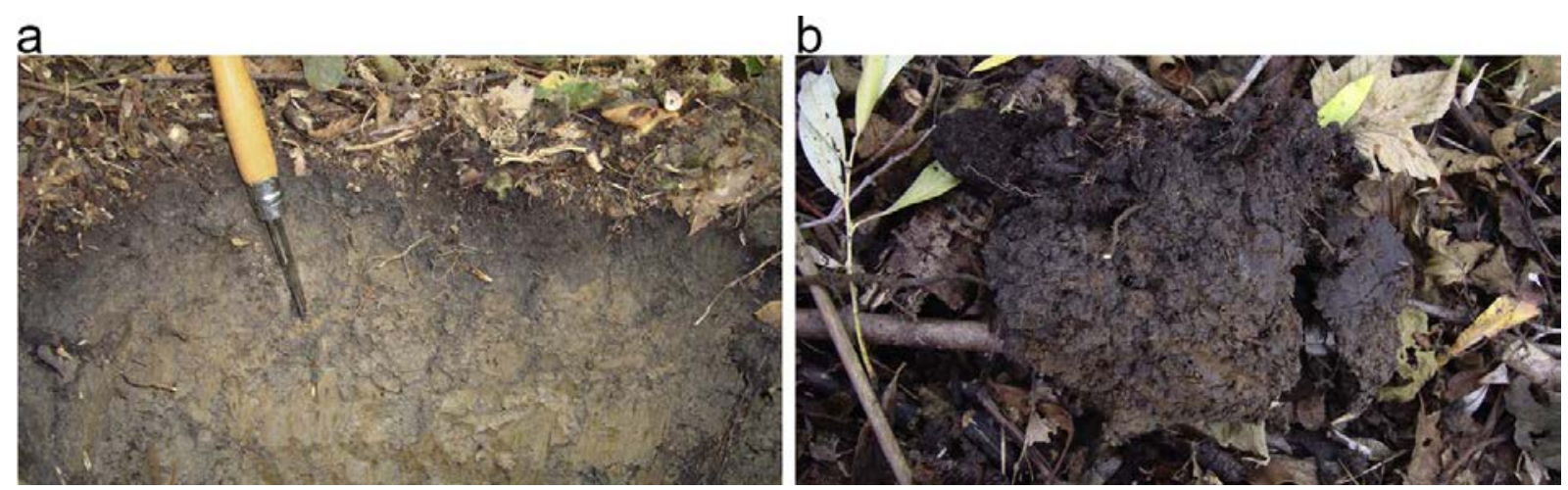

Fig. 5 


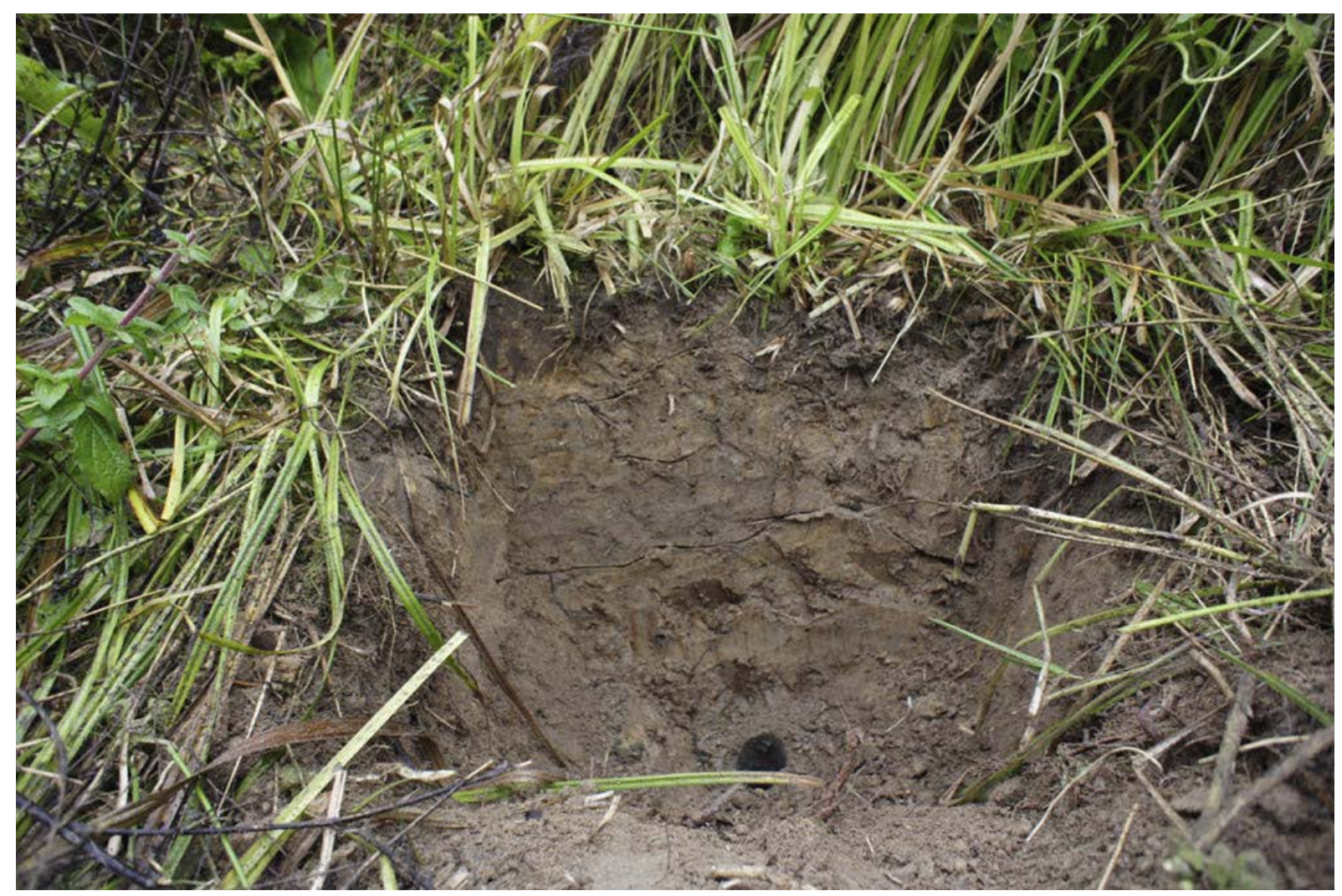

Fig. 6 


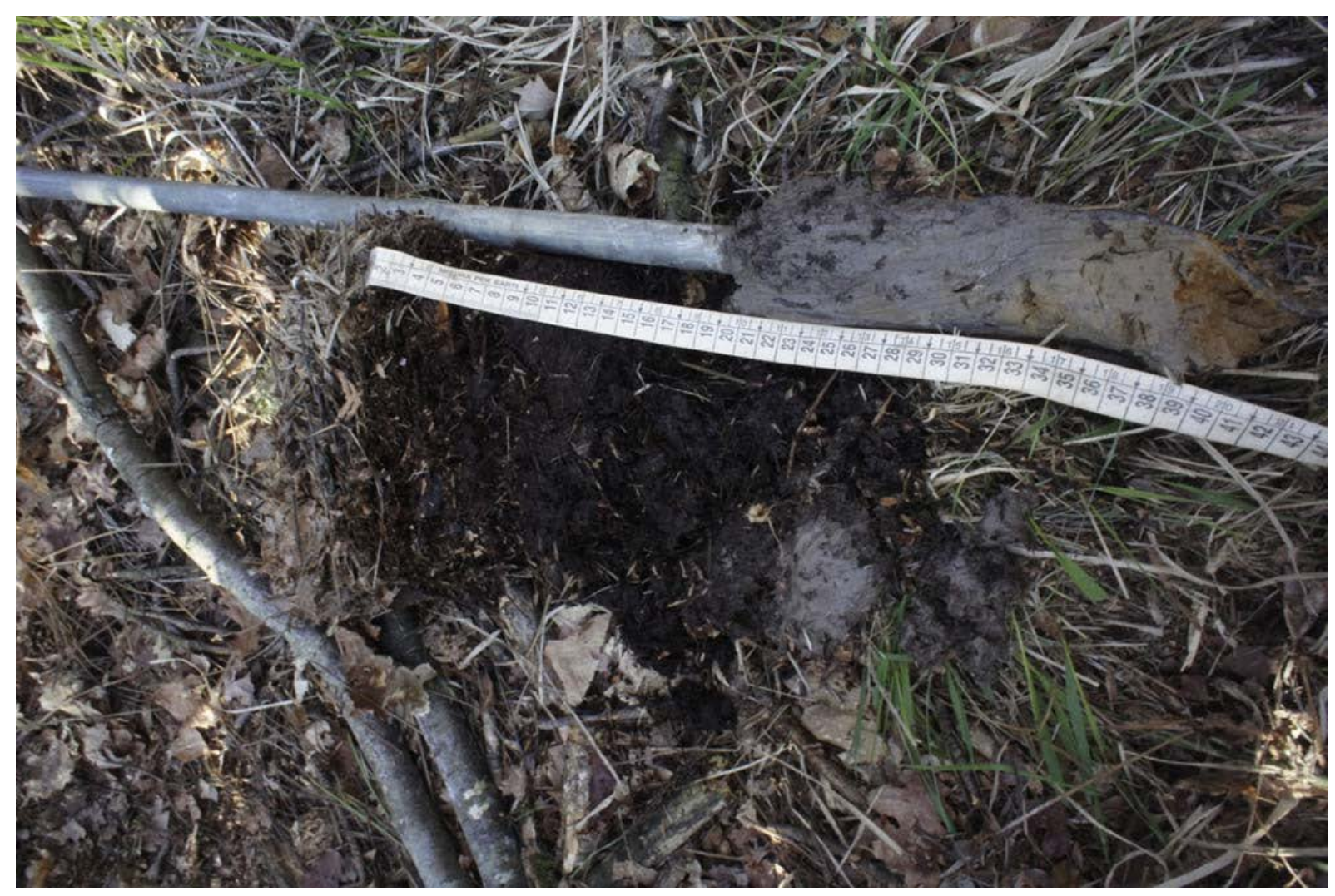

Fig. 7 


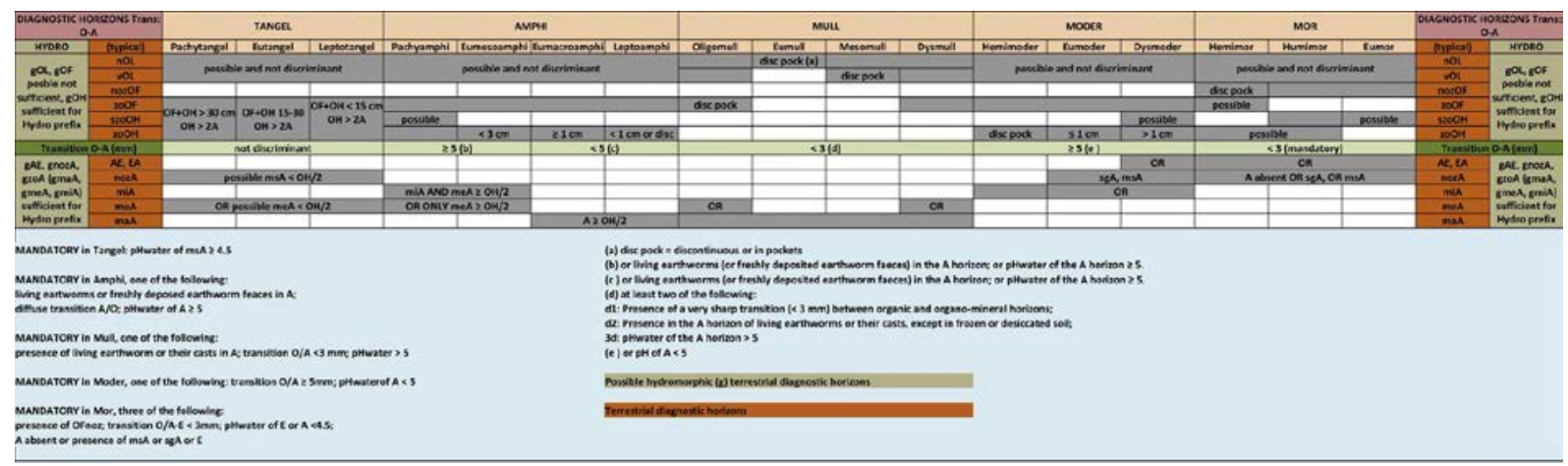

Fig. 8 